\title{
Structuring methodology of the Computerized Nursing Process in Emergency Care Units
}

\author{
Metodologia de estruturação do Processo de Enfermagem Informatizado para as Unidades de Emergência \\ Metodología de estructuración del Proceso de Enfermería Informatizado para las Unidades de Urgencia
}

Fernanda Paese', Grace Teresinha Marcon Dal Sasso', Gabriela Winter Colla'

'Universidade Federal de Santa Catarina. Florianópolis, Santa Catarina, Brazil.

How to cite this article:

Paese F, Dal Sasso GTM, Colla GW. Structuring methodology of the Computerized Nursing Process in Emergency Care Units. Rev Bras Enferm [Internet]. 2018;71(3):1079-84. DOI: http://dx.doi.org/10.1590/0034-7167-2016-0619

Submission: 12-16-2016 Approval: 04-17-2017

\section{ABSTRACT}

Objective: To structure the Computerized Nursing Process using the International Classification for Nursing Practice (ICNP $\left.{ }^{\circledR}\right)$ version 2.0 to emergency care units in a computerized structure. Method: This is a methodological and technological research that followed the stages: (1) establishment of the development team and resources; (2) adequacy of clinical situations, diagnoses and nursing interventions for the emergency area; (3) association of diagnoses and interventions based on ICNP ${ }^{\circledR}$; (4) organization and codification of clinical evaluation, diagnoses and nursing interventions; (5) transfer of data to the a computerized platform. Results: Readjustment and construction of 1,445 possibilities of clinical evaluations associated with 961 different diagnoses and their corresponding interventions to the most frequent situations in emergency services. Conclusion: ICNP ${ }^{\circledR}$ has a strong and solid form for the development of the computerized nursing process able to support nurses in safe decision-making to improve the quality of health care.

Descriptors: Emergency Medical Services; Electronic Health Records; Nursing Diagnosis; Patient Safety; Terminology.

\section{RESUMO}

Objetivo: Estruturar o Processo de Enfermagem Informatizado utilizando a CIPE ${ }^{\oplus}$ versão 2.0 para as unidades de emergência em uma estrutura informatizada. Método: É uma pesquisa metodológica e de produção tecnológica que seguiu as etapas: (1) estabelecimento da equipe de desenvolvimento e recursos; (2) adequação das situações clínicas, diagnósticos e intervenções de enfermagem para a área de emergência; (3) associação dos diagnósticos e intervenções a partir da CIPE ; (4) organização e codificação da avaliação clínica, diagnósticos e intervenções de enfermagem; (5) transferência dos dados para a plataforma computadorizada. Resultados: Readequação e construção de 1.445 possibilidades de avaliações clínicas associadas a 961 diferentes diagnósticos e suas correspondentes intervenções para as mais frequentes situações atendidas nos serviços de emergência. Conclusão: A CIPE possui uma forma robusta e sólida para o desenvolvimento do processo de enfermagem informatizado capaz de apoiar o enfermeiro na tomada de uma decisão segura de modo a melhorar a qualidade da assistência. Descritores: Serviços de Atendimento de Emergência; Registros Eletrônicos de Saúde; Diagnóstico de Enfermagem; Segurança do Paciente; Terminologia.

\section{RESUMEN}

Objetivo: Estructurar el Proceso de Enfermería Informatizado utilizando CIPE ${ }^{\oplus}$ versión 2.0 para las unidades de urgencia en una estructura informatizada. Método: Es una investigación metodológica y de producción tecnológica que siguió las etapas: (1) el establecimiento del equipo de desarrollo y recursos; (2) la adecuación de las situaciones clínicas, diagnósticos e intervenciones de enfermería para el área de urgencia; (3) la asociación de los diagnósticos e intervenciones desde CIPE ; (4) la organización y la codificación de la evaluación clínica, diagnósticos e intervenciones de enfermería; (5) la transferencia de los datos para la plataforma computadorizada. Resultados: La readecuación y la construcción de 1.445 posibilidades de evaluaciones clínicas asociadas a 961 distintos diagnósticos y sus correspondientes intervenciones para las más frecuentes situaciones atendidas en los servicios de urgencia. Conclusión: CIPE posee una manera robusta y sólida para el desarrollo del proceso de enfermería informatizado capaz de apoyar el enfermero en la toma de una decisión segura de modo a mejorar la cualidad de la asistencia.

Descriptores: Servicios de Atención de Urgencia; Registros Electrónicos de Salud; Diagnóstico de Enfermería; Seguridad del Paciente; Terminología.

\section{CORRESPONDING AUTHOR Fernanda Paese E-mail: fernandapaese@hotmail.com}




\section{INTRODUCTION}

The importance of produced and documented data resulting from health care practice of nurses have, in recent decades, represented a challenge to the development of information technologies, essentially due to the needs of information and difficulties in its management.

The need for access to information has been increasing for those involved in the health care process. On one hand, there is a higher involvement of citizens in decisions about their health; simultaneously, health professionals require that clinical information are present at the right time and place, regardless of the source or of the unit care. On the other hand, public administrators and policy makers want to have information to define policies, management programs and to monitor the quality of provided cares ${ }^{(1)}$.

Health Information Technology (HIT) is playing an increasing role as a tool for patient care, and some HIT components have improved the quality of care in health and have reduced errors $^{(2)}$. With HIT advances in recent years, mainly in the health care area, different forms of Electronic Health Records (EHR) have been discussed, developed and implemented. When health information technologies are properly designed and implemented, they can improve the performance of health professionals, support better communication between patients and health professionals, improve the patient safety and, consequently, provide a better service ${ }^{(3)}$.

In the nursing field, the electronic record through the nursing process has the purpose of supporting the requirements and demands of different data that integrate patient care and the need for information exchange between the health care team, as well as the challenge of adopting nursing terminologies ${ }^{(4)}$.

Accordingly, the World Health Organization (WHO), aware of the need of a common language in the nursing area, recommended to the International Council of Nurses (ICN) a system of classification of terms whose purpose is to standardize a universal language for Nursing. It aims to represent the concepts and cares of nursing practice, allowing comparisons between data of different populations and times, besides contemplating problems/diagnoses, interventions and nursing outcomes ${ }^{(5)}$.

Nursing documentation systems use different types of standardization, terminology or classification systems inside electronic health records. The use of these documentation systems is a recent movement in nursing, and the efforts for its development are related to the need of language standardization ${ }^{(6)}$.

In 1989, the ICN presented the proposal of the International Classification for Nursing Practice (ICNP $\left.{ }^{\circledR}\right)$ as a tool for information exchange, with the potential to identify the contribution of nursing in healthcare and to influence on the planning of health policies ${ }^{(5)}$.

Over the years, ICNP ${ }^{\circledR}$ changed its structure, content and hierarchical presentation of terms and has been presenting itself as a feasible option with linguistic, cognitive and technological advantage ${ }^{(7)}$. Therefore, this nursing classification was chosen as theoretical and methodological coordinate for this research.

From these developments, since 1999, studies sought to develop and evaluate the Computerized Nursing Process (CNP) in Intensive Care Units (ICU) using the $\mathrm{ICNP}^{\oplus}$ as a terminology reference. The first studies used ICNP ${ }^{\circledast}$ Beta 2 Version. In each research carried out, CNP was evaluated and new modifications were implemented ${ }^{(8)}$.

Technological productions, subsequently developed and evaluated, proved that CNP could be implemented in ICU and gave recommendations for future research, as well as prospects of CNP constructions to other health care areas.

\section{OBJECTIVE}

This study aimed to structure and organize the data and information of the Computerized Nursing Process through ICNP ${ }^{\circledR}$ Version 2.0 for emergency units, aiming to prove the hypothesis that it is possible to structure the nursing process according to an international terminology in an informational structure based on clinical situations with different degrees of complexity.

\section{METHOD}

\section{Ethical aspects}

The study was submitted to the Ethics Committee, being approved without reservations by the members of the entity and followed the legal precepts for the development of research involving human subjects.

\section{Study design, location and period}

This is a hybrid research with quantitative and methodological nature that addressed technological production and adopted the development stages ${ }^{(9)}$ of the Computerized Nursing Process using ICNP ${ }^{\infty}$ Version 2.0 to emergency units from the selection and readjustment of the database and information of the Computerized Nursing Process according to the ICNP ${ }^{\circledR}$ Version 1.0 to Intensive Care Unit. The research was the used in a Masters Thesis and a Doctoral Dissertation in the Graduate Program in Nursing of the Federal University of Santa Catarina (UFSC) ${ }^{(10-11)}$.

It is part of the macro research project of Grupo de Pesquisa Clínica, Tecnologias and Informática em Saúde e Enfermagem (Group of Clinical Research, Technologies and Information Technology in Health and Nursing - GIATE/PEN/UFSC) named as Registro Eletrônico de Enfermagem e (Tele)Monitoramento em Saúde para a Rede de Atenção à Urgência e Emergência (RUE) no Estado de Santa Catarina, e-RUE (Electronic Record of Nursing and (Tele)Monitoring in Health to the Network of Health Care to Urgency and Emergency (RUE) in the State of Santa Catarina, e-RUE ${ }^{\circ}$, which aims to develop and analyze an electronic record system and (Tele)Monitoring in health that allows to integrate, incorporate and monitor data and information among various components of Rede de Urgência e Emergência (Network of Urgency and Emergency).

Structuring of the Computerized Nursing Process for the information record of the patient treated in emergency services was carried out in the GIATE/UFSC laboratory of clinical research, in Florianópolis from October 2012 to March 2015.

\section{Sample and inclusion criteria}

The study counted on the participation of an $\mathrm{PhD}$ professor in nursing - coordinator of the project -, a Doctoral Degree 
student of the Graduate Program in Nursing (from the Portuguese acronym, PEN) of UFSC, a student of a PEN Master's Degree/UFSC, an undergraduate student in nursing from UFSC and scholarship holder of Scientific Initiation - CNPq and two system programmers.

The inclusion criterion was to be a nurse and/or undergraduate student in nursing. For systems programming experts, they should have been active in the areas of computer science or systems analysis.

It is important to report that as a by-product of the e-RUE ${ }^{\oplus}$ macro project, it was obtained the doctoral dissertation of the author of this manuscript. The study presents the development of the Computerized Nursing Process from ICNP ${ }^{\circledast}$ Version 2.0 for emergency health care services as a part of the thesis.

\section{Study protocol}

The study followed these stages:

- Stage 1: Establishment of the development team and resources to data structure organization.

This step was the beginning of the development of the eRUE $^{\circledast}$ project with approval of funding by Fundação de Amparo à Pesquisa e Inovação do Estado de Santa Catarina (Foundation for Research and Innovation Support of the State of Santa Catarina - FAPESC) and choice of the development team and resources needed for the data structure organization.

It is worth mentioning that the development team adopted the $\mathrm{ICNP}^{\circledR}$ Version 2.0 because it contemplated the highest number of diagnoses and interventions up to its new update. Studies of the project began in 2012 and the entire first part of mapping of diagnoses and interventions was based on such version. ICNP ${ }^{\circledast}$ has a premise to update its nursing concepts catalog every two years - last updated in 2013 and 2015. Therefore, we decided to use Version 2.0, with which the study had begun.

- Stage 2: Adequacy of clinical situations, diagnoses and interventions of nursing used in the Computerized Nursing Process according to the ICNP ${ }^{\circledast}$ Version 1.0 for Intensive Care Unit (ICU).

The CNP for ICU was structured from groupings of three to four clinical situations for each human system, according to the complexity order, aiming to cover the totality of clinical evaluation items of a patient admitted to an ICU ${ }^{(11)}$ associated with diagnoses and interventions of nursing.

From this composition, the group of researchers selected and readjusted the nursing process (clinical evaluation, diagnoses and interventions of nursing) to the most common clinical situations in emergency care services, and followed with the division in human systems and with four clinical situations for the cardiovascular, respiratory, neurological and renal systems; three clinical situations for the integumentary, musculoskeletal, gastrointestinal, psychological, male reproductive and female reproductive systems aiming to cover the highest possibility of diagnoses and interventions for emergency situations.

- Stage 3: Association of nursing diagnoses and interventions based on ICNP ${ }^{\circledast}$ Version 2.0 for each clinical situation.
This stage was based on the clinical evaluation items of every human system with a set of diagnoses and interventions of nursing already associated, i.e., in this stage we already had diagnoses associated with nursing interventions. It was also necessary to choose the diagnoses for each item of the clinical evaluation and more suitable interventions. For all this process, we used several studies, and it was required from the nurses the integration of professional practice, research and theory and, mainly, the clinical reasoning when facing the various possibilities of associations.

- Stage 4: Organization and coding of clinical evaluation, diagnoses and interventions of nursing to integrate them to the computational environment of the e-RUE ${ }^{\circledast}$ platform.

$\mathrm{ICNP}^{\circledast}$ in its 7-Axis Model (Focus, Judgment, Means, Action, Time, Location and Client) brings in its composition specific codes to each name ${ }^{(12)}$, which differentiated diagnoses and interventions. It is worth mentioning that the publications up to the ICNP ${ }^{\otimes}$ Version 2.0 did not contemplate the needs for interventions to the contexts of emergency services scenarios, therefore, hundreds of interventions created during this process were coded with proper numbering to compose the system.

It was also prepared a proper coding to organize the clinical evaluation item and connect them to the respective diagnoses and interventions.

In this process, it was essential to construct a relational matrix able to contemplate the human systems, codes of nursing diagnoses, classification by level of complexity of the four clinical situations prepared and their respective nursing interventions.

- Stage 5: Transfer of data to the e-RUE ${ }^{\circledast}$ computerized platform.

To start this last stage of the system development, the group of nurses conducted a detailed review of the data before importing them. All data were organized primarily in Excel ${ }^{\circledR}$ worksheets divided by level of complexity and human systems and, subsequently, transferred to the informational platform.

The technology chosen to access the system data was MongoDB tool, due to its characteristics that better meet the needs of a system compatible with the requirements of this research. MongoDB is a database orientated to documents of high performance for large volume of data, one of the major factors in its choice, given the immense amount of data involved. It is capable of storing data in collections through nonrigid structures, i.e., in vaguely defined documents, allowing the addition of new attributes to individual documents without other changes ${ }^{(13)}$.

Another important characteristic for its use in this project is the flexibility of its data structure, enabling adaptations and improvements in a quick and reliable way. This means that the system has a tool allows adding information without modifying the existing ones with potential system updates from the use and experience of the user of the system.

\section{Analysis of the results and statistics}

Since the computerized system was a final product of the methodological research proposal, we consider data collection, organization and analysis, respectively, and the search in the literature in the area of clinical nursing in critical health 
situation, as well as, and especially, with the already structured language of the ICNP ${ }^{\circledast}$; the data organized in Excel $^{\circledast}$ worksheets and divided by human systems and degrees of complexity; and finally, its analysis from the structuring of diagnoses and nursing interventions clinically associated with the nursing process.

\section{RESULTS}

After the initial bases were updated and readjusted to the main clinical situations of emergency care services, the system passed through innovative modifications to nursing health care in emergency situations. The access of the nurse to the system is through risk classification. The system simultaneously provides the option of classifying the patients from their clinical demand, as well as record their vital signs, evaluation of consciousness level (Glasgow Coma Scale) and evaluation of Cerebrovascular Accident in acute phase (NIH Stroke Scale - National Institute of Health Stroke Scale).

When patients have their clinical priority established by the Manchester Triage System ${ }^{\circledR}$, the system sequentially presents the options of viewing the history of previous service, reperforming the risk classification - important item and extolled by the Manchester Triage protocol - so that patients are evaluated according to the change in their medical condition, reregistering the vital signs and the results of scales extolling that these data can be registered as many times as necessary and performing the nursing process record (clinical evaluation, diagnoses and interventions of nursing). The adaptation of the system is also possible, i.e., if another risk classification is introduced at the institution, nurses will still have at their disposal the Computerized Nursing Process.

When the nurse selects data and information on the clinical evaluation of a certain human system, the system offers a set of possible nursing diagnoses. They do not appear selected, i.e., the nurse must choose the diagnosis that best matches the clinical condition of the patient at that time. However, this set aims to support the nurse's decision-making.
While the nurse is selecting the diagnoses, corresponding interventions will appear and compose the nursing process. Regarding interventions, the system already brings them selected and the nurse must evaluate and remove them if it is not necessary.

Figures 1 and 2 show this process.

Figure 1 presents the nine human systems and with the selection of the renal system, being the first item of "Pain" evaluation with the options of Pain - Absent - Present. When the system displays the evaluation item in bold, it has the option of opening for the evaluation of the characteristics, as for example, Pain Present in the Flank and Pain Present in the Lumbar Region.

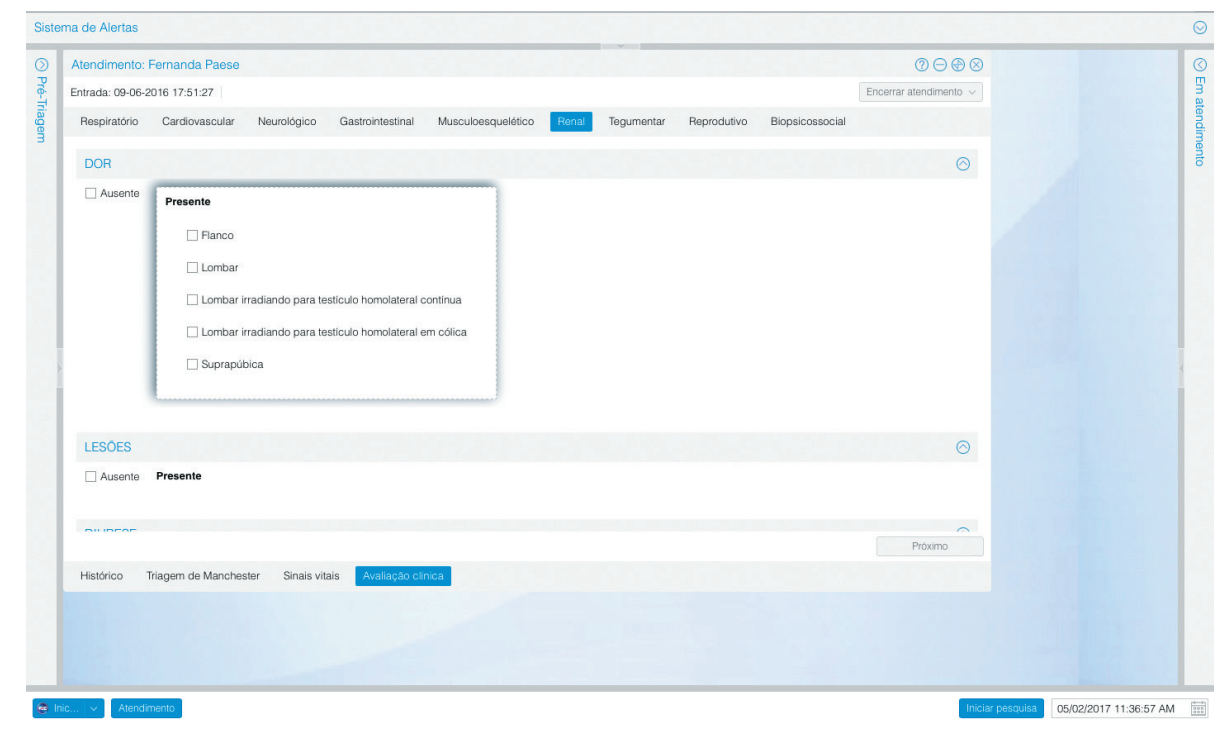

Source: Electronic Registration System e-RUE $E^{\circledR}$, Florianópolis, Santa Catarina, Brazil.

Figure 1 - Presentation of Clinical Evaluation with division of Human Systems and pain evaluation in Renal System

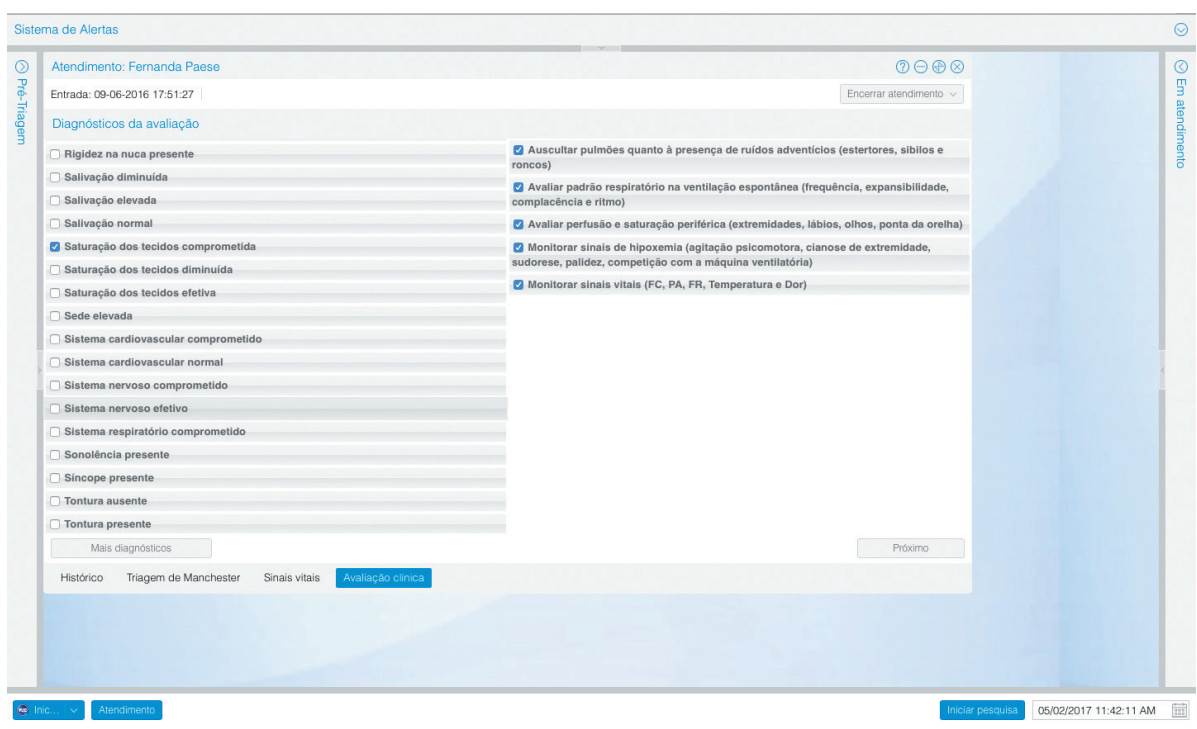

Source: Electronic Registration System e-RUE, Florianópolis, Santa Catarina, Brazil.

Figure 2 - List of suggested diagnoses, from clinical evaluation with corresponding nursing interventions 
Association of clinical evaluations by human systems to nursing diagnoses and interventions according to ICNP ${ }^{\circledR}$ Version 2.0 started from 1,349 possibilities of clinical evaluations, 949 different diagnoses and 438 different previously selected interventions and readjusted from the database of Computerized Nursing Process according to the ICNP ${ }^{\circledR}$ Version 1.0 for ICU ${ }^{(10-11)}$. From the need to contemplate the specificities of emergency care services, there were readjusted, from the aforementioned studies, new concepts creating 1,445 possibilities of clinical evaluations, 961 different diagnoses and 953 different nursing interventions.

\section{DISCUSSION}

The Computerized Nursing Process from the proposed methodology made it possible to understand that ICNP ${ }^{\circledR}$ Version 2.0, while reference terminology, provided the basis for the clinical reasoning of the nurse to urgency and emergency units. From the expertise of the involved researchers, we found that it was possible to systematize clinical situations with different degrees of complexity and that logical responses were found in ICNP ${ }^{\circledast}$ nursing diagnoses and interventions, by integrating data and knowledge into an electronic record system.

$\mathrm{ICNP}^{\circledast}$ can manage critical data to document nursing practices and to one understand about the nursing work in global health care scenario based on knowledge. ICN considers the Information and Communication Technologies fundamental to $\mathrm{ICNP}^{\circledast}$, since it is an instrument used by an increasingly growing number of people in the world, by improvement of technological capacity and expansion of international standards concerning terms and concepts of health care and relations inherent to terminologies ${ }^{(5)}$.

Information and Communication Technologies in Nursing provide instruments for improving health care by electronically linking evaluations, interventions and outcomes and to support the decision-making process ${ }^{(14)}$. Electronic Health Records can help improving the quality and costs of care, meeting the clinical and procedural needs by capturing, storing and displaying clinical information when and where they are needed to improve the individual service of the patient $t^{(3)}$.

With the readjustment and new structuring of data to the Computerized Nursing Process, the nurse can perform the care with more quality and safety, once it is possible to organize, relate and integrate as many clinical evaluations, diagnoses and nursing interventions as possible. Thus, the Computerized Nursing Process becomes a great ally of nurses, being able to support them in the clinical decision-making process, and allowing a rapid response in urgency and emergency units without replacing the direct care to the patient.

We emphasize that this informational platform also considers the risk classification proposed by the Manchester Triage System ${ }^{\circledast}$ associated with the connections of diagnoses and nursing interventions of ICNP ${ }^{\varpi}$ Version 2.0, as aforementioned. It is also worth remarking that risk classification is an indispensable device for a more effective work process, with fundamental importance to assess of the patient, allowing the increase of access, as well as its fair offer ${ }^{(15)}$.
All this structuring tends to offer the nursing professional a tool that helps in decision-making and in performing an adequate clinical and risk evaluation in emergency care units.

\section{Study limitations}

A limit of this study is the need to choose three and four clinical situations for each human system as a basis of clinical reasoning of nursing evaluations, diagnoses and interventions for emergency situations. We believe that, with the use of electronic record system, more diagnoses and interventions can be aggregated by the nurses to the system and, over time, they can make it even more complete.

\section{Contributions to the Nursing field}

This study contributed to the development of an electronic record system for emergency care services that can contribute to improve the systems built to document the NP, as well as to support future studies that have interest in replicating the development method, and structure the CNP in other scenarios of nursing practice.

Thus, an important contribution for nursing is the improvement of assistance record tools, since the system uses an international terminology related to information technology capable of supporting clinical decision, providing communication between the pairs and giving visibility to the work of the nurse as a member of the health care team.

\section{CONCLUSION}

The development of such research enabled the association of 1,445 possibilities for clinical evaluations with 961 different diagnoses and 953 different nursing interventions, distributed among the nine human body systems, emphasizing that the Nursing Process based on ICNP ${ }^{\circledR}$ Version 2.0, besides being able to be computerized, can be adapted to the different realities of nursing care.

When adopting ICNP ${ }^{\circledast}$, we understand that the combination of information technology and Computerized Nursing Process is the solid path for the development of nursing care, providing accurate and complete information for the care unit, coordinating the care from quick access to the records, providing a complete documentation for the nursing staff, optimizing and organizing the time of nurses and, consequently, a safe care.

The database developed in this study was structured to nursing care in emergency units; however, its broad structure allows its adaptation to other nursing care scenarios. The data generated enabled the extraction of information to evaluate security indicators, nursing outcomes (change of diagnosis from interventions carried out by the nurse), as well as the clinical reasoning of nurses in the construction of the Nursing Process and, especially, to demonstrate the work of nurses as part of a science still in a development stage.

In this context, this research can contribute to improve the electronic record systems developed to document the Nursing Process. This study opens opportunities for new studies involving nurses in different areas of health care by integrating information and communication technologies and the Nursing Process. 


\section{FUNDING}

Foundation for Research and Innovation Support of the State of Santa Catarina - FAPESC that financed the macro research project titled as "Electronic Record of Nursing and (Tele)Monitoring in Health to the Network of Health Care to Urgency and Emergency (RUE) in the State of Santa Catarina, e-RUE ${ }^{\oplus \prime}$ and National Council for Scientific and Technological Development (CNPq).

\section{REFERENCES}

1. Sousa P. Information Systems in Nursing: new challenges, new opportunities... Rev Esc Enferm USP [Internet]. 2012[cited 2014 Apr 18];46(5):1-2. Available from: http://www.scielo.br/pdf/reeusp/v46n5/en_01.pdf

2. US. Institute of Medicine. Committee on Patient Safer Systems for Better Care. Health IT and Patient Safety: building safer systems for better care. Washington, DC: The National Academies Press, 2012.

3. Nelson R, Staggers N. Health Informatics: An Interprofessional Approach. St. Louis: Missouri, USA: Elsevier; 2014.

4. Häyrinen K, Saranto K, Nykänen P. Definition, structure, content, use and impacts of electronic health records: a review of the research literature. Int J Med Inform[Internet]. 2008 [cited 2015 Oct 13];77(5):291-304. Available from: http://www.ncbi.nlm.nih. gov/pubmed/17951106

5. International Council of Nurses. Classificação Internacional para a Prática de Enfermagem (CIPE ${ }^{\circledR}$ - Versão 1.0. Marin HF(Trad.). São Paulo, 2007.

6. Peres HHC, Lima AFC, Cruz DALM, Gaidzinski RR, Oliveira NB, Ortiz DCF, et al. Assessment of an electronic system for clinical nursing documentation. Acta Paul Enferm[Internet]. 2012 [cited 2015 Dec 21];25(4):543-8. Available from: http://dx.doi. org/10.1590/S0103-21002012000400010

7. Veríssimo RCSS, Marin HF. Documentation system prototype for postpartum nursing. Acta Paul Enferm[Internet]. 2013 [cited 2016 Jan 06];26(2):108-15. Available from: http://www.scielo.br/pdf/ape/v26n2/v26n2a02.pdf

8. Dal Sasso GTM, Barra DCC, Paese F, Almeida SRW, Rios GC, Marinho MM, et al. Computerized nursing process: methodology to establish associations between clinical assessment, diagnosis, interventions, and outcomes. Rev Esc Enferm USP [Internet]. 2013[cited 2015 Dec 30];47(1):242-9. Available from: http://www.scielo.br/pdf/reeusp/v47n1/en_a31v47n1.pdf

9. Polit DF, Beck CT. Fundamentos de pesquisa em enfermagem: avaliação de evidências para a prática de enfermagem. 7th ed. Porto Alegre: Artmed; 2011. 669p.

10. Almeida SRW. Aplicação do processo de enfermagem informatizado a partir da CIPE versão 1.0 em uma UTI geral[Dissertação]. Programa de Pós-Graduação em Enfermagem, Universidade Federal de Santa Catarina; 2011.

11. Barra DCC. Processo de enfermagem informatizado e a segurança do paciente em terapia intensiva a partir da CIPE ${ }^{\circledast}$ versão 1.0: a evidência clínica para o cuidado[Tese]. Programa de Pós-Graduação em Enfermagem, Universidade Federal de Santa Catarina; 2012.

12. International Council of Nurses. Classificação Internacional para a Prática de Enfermagem - CIPE Versão 2.0 - do original ICNP ${ }^{\circledR}$ Version 2 - Internacional Classification for Nursing Practice. Lisboa. Ordem dos Enfermeiros, 2011.

13. Banker K. MongoDB in action. New York: Ed. Manning Publications Co [Internet]. 2012. [cited 2015 Dec 10]. Available from: http://img105.job1001.com/upload/adminnew/2015-04-07/1428394945-PHQK1Q5.pdf

14. Dal Sasso GT, Silveira DT, Barbosa SF, Évora YD, Marin HF. Tecnologias da informação e da comunicação em enfermagem e teleenfermagem. In: Prado C, Peres HH, Leite MM, (Eds.). Tecnologia da informação e da comunicação em enfermagem. São Paulo: Atheneu; 2011. p. 112-25.

15. Camara RF, Paulino TS, Pereira FCC, Nelson ICASR, Rocha KM, Neto LI. O papel do enfermeiro no processo de classificação de risco na urgência: uma revisão. Rev Hum Ser[Internet]. 2015 [cited 2016 Jan 02];1(1):99-114. Available from: http://periodicos. unifacex.com.br/humanoser/article/view/628/146 